\title{
STUDI PEMBUATAN PERMEN KURMA (Phoenix dactylifera L.) DENGAN PENAMBAHAN EKSTRAK LEMON (Citrus limon)
}

\author{
\{STUDY OF MAKING CANDY KURMA (Phaoenix dactylifera L.) DENGAN PENAMBAHAN \\ EKSTRAK LEMON (Citrus limon)\} \\ Jiniatunnissa BR Sitepu and Zulkifli Lubis \\ Fakultas Pertanian Universitas Muhammadiyah Sumatera Utara \\ Email: juniatunnissabrsitepu19@gmail.com
}

\begin{abstract}
Candy is a food that is liked much by children and adults. Now, there are many sweets that are circulating in the society namely Jelly candies. However, most of the sweets in the market are only concerned with the taste and appearance without the importance of health, so it needs to be developed that sweets can be good for the body, for example by using palm fruit and lemon extract. This research aims to find out how to manufacture date candies with basic materials of dates and lemons and know the comparison of the sweetness and acidity that much liked panelist. The study used the complete random draft (RAL) method with two factorial. Factor I is the amount of date fruit meat (K) consisting of 4 treatments, namely $\mathrm{K}_{1}=30 \mathrm{~g}, \mathrm{~K}_{2}=25 \mathrm{~g}$, $\mathrm{K}_{3}=20 \mathrm{~g}, \mathrm{~K}_{4}=15 \mathrm{~g}$. Factor II is the amount of lemon extract (L) consisting of 4 treatments, namely $\mathrm{L}_{1}=20 \mathrm{ml}, \mathrm{L}_{2}=15 \mathrm{ml}, \mathrm{L}_{3}=10 \mathrm{ml}, \mathrm{L}_{4}=5 \mathrm{ml}$. The observed parameters are moisture content, ash content, reduction sugar test, Sakarosa test, organoleptic taste test and organoleptic test texture. From the results of static analysis of each parameter: The amount of date fruit meat gives a different effect very real $(p<0,01)$ against water content test, ash content, sugar reduction and Sakarosa while the lemon extract provides a different effect is very noticeable $(p<0,01)$ against water content test, sugar reduction, organoleptic flavor and organoleptic texture.
\end{abstract}

Keywords: Palm fruit, Lemon juice, Jelly candy and functional food.

\section{PENDAHULUAN}

Kemajuan di zaman yang modern ini sangatlah beragam, mulai dari teknologi, makanan, minuman, cemilan dan sebagainya. Buah Kurma adalah buah yang manis dan sedikit legit merupakan buah yang popular di bulan Ramadhan, tetapi pada hari-hari biasa peminatnya sangat kurang. Buah kurma sendiri bermanfaat bagi tubuh salah satunya adalah untuk kesehatan mata, karena buah kurma juga mengandung vitamin A dan banyak nutrisi lain apabila mengkonsumsi buah kurma tersebut.

Menurut pendapat Cahyo (2010), kurma banyak mengandung nutrisi yang berguna bagi tubuh seperti kandungan zat besinya yang tinggi dapat membantu pembentukan hemoglobin yang dapat membantu mempercepat metabolisme dalam sel. Bone (2013) mengemukakan bahwa kurma mengandung flavonoid yang dapat bermanfaat sebagai antioksidan, anti inflamasi (anti peradangan/pembengkakan), anti mikroba dan perangsang regenerasi hati.

Buah lemon terkenal akan kandungan vitamin $\mathrm{C}$ nya, namun faktanya buah lemon memiliki banyak zat gizi esensial meliputi $\mathrm{KH}$ (serat dan gula), Ca, Potasium, Folat, Asam pantotenat Niacin, Thiamin, Vit B6, P, Mg, $\mathrm{Cu}$, Senyawa Fitokimia serta Riboflavin. KH dalam lemon meliputi glukosa, fruktosa dan sukrosa. Polisakarida non-pati (serat makanan) yang baik untuk kesehatan termasuk KH kompleks dalam buah lemon (Nizhar, 2012).

Soft candy dibuat melalui proses penampuran gula yang dimasak bersamaan dengan bahan penstabil serta ditambahkan cita rasa dan warna kemudian dicetak. Sukrosa berperan dalam pangan karena memiliki banyak 
fungsi salah satunya sebagai pembentuk tekstur, pemanis, pembentuk cita rasa dan pengawet (Wahyuni, 1998).

Penganekaragaman pangan fungsional menjadikan daging buah kurma sebagai bahan utama dalam pembuatan permen, selain terdapat kandungan vitamin dan serat yang tinggi yang banyak manfaatnya bagi tubuh dan masih banyak kandungan lainnya. Selain penggunaan daging buah kurma, juga dilakukan penambahan ekstrak lemon yang diperoleh dari pengambilan sari buah lemon dengan cara diblender. Jeruk lemon memiliki kandungan asam sitrat yang cukup banyak. Pada pembuatan permen, asam sitrat berfungsi dalam pembentukan tekstur yang baik pada permen, menambah cita rasa, aroma pada permen yang dihasilkan,

\section{B. METODOLOGI PENELITIAN}

\section{Bahan dan Alat}

Bahan yang digunakan antara lain buah kurma, buah lemon, sirup fruktosa, sukrosa

Alat yang digunakan antara lain : Baskom, Blender, Panci, Kompor, Pengaduk, Timbangan analitik, Sendok, Telenan, Saringan, Beaker gelas, Tabung reaksi, Termometer, Pisau dan Wadah. Untuk cawan porselin, oven, desikator dan alat pendukung lainnya

Penelitian dilakukan dengan Rancangan Acak Lengkap (RAL) faktorial yang terdiri dari dua faktor yaitu :

Faktor I : Jumlah daging buah kurma (K) terdiri dari 4 taraf yaitu: $\mathrm{K}_{1}=30 \mathrm{~g}, \mathrm{~K}_{2}=25 \mathrm{~g}, \mathrm{~K}_{3}=20 \mathrm{~g}$, $\mathrm{K}_{4}=15 \mathrm{~g}$. Faktor II : Perbedaan jumlah penambahan ekstrak lemon (L) terdiri dari 4 taraf yaitu : $\mathrm{L}_{1}=20 \mathrm{ml}, \mathrm{L}_{2}=15 \mathrm{ml}, \mathrm{L}_{3}=10 \mathrm{ml}, \mathrm{L}_{4}=$ $5 \mathrm{ml}$. Penelitian dilakukan ulangan sebanyak 2 (dua) kali untuk ketelitian penelitian. Analisa data menggunakan nilai kritis uji Duncan dinyatakan dalam nilai Least Significant Range (LSR) atau wilayah nyata terkecil.

Parameter pengamatan yang digunakan meliputi Uji Kadar Air, Uji Kadar Abu, Uji Gula Reduksi, Uji Sakarosa, Uji Organoleptik Rasa dan Uji Organoleptik Tekstur.

\section{Prosedur Kerja \\ Pemisahan Daging Buah Kurma dari bijinya}

Buah kurma di sortasi, dipilih yang kualitasnya baik, tidak keras. Dipisahkan dari biji dan tangkainya. Setelah itu daging buah kurma dipotong kecil-kecil. Lalu ditimbang sebanyak 30g, 25g, 20g, 15g.

\section{Pembuatan Ekstrak Lemon}

Pencucian buah lemon dilakukan terlebih dahulu, selanjutnya kulit lemon dikupas dan lemon dipotong menjadi dua bagian dan buang biji pada lemon. Lalu lemon diblender selanjutnya disaring.

\section{Pembuatan Permen}

Blender sukrosa sebanyak $75 \mathrm{~g}$ hingga menjadi bubuk lalu masukkan dalam wadah. Campurkan sirup fruktosa sebanyak $25 \mathrm{~g}$ dan ekstrak lemon sesuai perlakuan $\mathrm{L}_{1}: 20 \mathrm{ml}, \mathrm{L}_{2}$ : $15 \mathrm{ml}, \mathrm{L}_{3}: 10 \mathrm{ml}$ dan $\mathrm{L}_{4}: 5 \mathrm{ml}$. Masak semua bahan hingga suhu $100^{\circ} \mathrm{C}$, kemudian masukkan daging buah kurma sesuai perlakuan $\mathrm{K}_{1}: 30 \mathrm{~g}, \mathrm{~K}_{2}$ : 25g, $\mathrm{K}_{3}: 20 \mathrm{~g}$ dan $\mathrm{K}_{4}: 15 \mathrm{~g}$, lalu masak semua bahan hingga suhu $140^{\circ} \mathrm{C}$, angkat kemudian cetak permen. Dinginkan pada suhu ruang. Lakukan parameter pengamatan.

\section{HASIL DAN PEMBAHASAN}

Hasil penelitian dan uji statistik secara umum menunjukkan bahwa jumlah daging buah kurma dan jumlah ekstrak lemon memiliki pengaruh terhadap parameter yang diamati. Data rata-rata hasil pengamatan pengaruh jumlah daging buah kurma dan jumlah ekstrak lemon pada masing-masing parameter dapat dilihat pada Tabel 5 dan Tabel 6 .

\begin{tabular}{|c|c|c|c|c|c|c|}
\hline \multirow[b]{2}{*}{$\begin{array}{c}\text { Jumlah } \\
\text { Kurma } \\
\text { (g) }\end{array}$} & \multirow[b]{2}{*}{$\begin{array}{c}\text { Kadar } \\
\text { Air } \\
(\%)\end{array}$} & \multirow[b]{2}{*}{$\begin{array}{c}\text { Kadar } \\
\text { Abu } \\
(\%)\end{array}$} & \multirow{2}{*}{$\begin{array}{c}\text { Kadar } \\
\text { Gula } \\
\text { Reduksi } \\
(\%)\end{array}$} & \multirow[b]{2}{*}{$\begin{array}{c}\text { Sakarosa } \\
(\%)\end{array}$} & \multicolumn{2}{|c|}{ Uji Organoleptik } \\
\hline & & & & & Rasa & Tekstur \\
\hline $\mathrm{K}_{1}: 30 \mathrm{~g}$ & 3,775 & 2,721 & 24,625 & 34,525 & 3,283 & 3,284 \\
\hline $\mathrm{K}_{2}: 25 \mathrm{~g}$ & 3,513 & 2,486 & 24,088 & 33,638 & 3,323 & 3,324 \\
\hline $\mathrm{K}_{3}: 20 \mathrm{~g}$ & 3,300 & 1,640 & 23,600 & 33,363 & 3,388 & 3,390 \\
\hline $\mathrm{K}_{4}: 15 \mathrm{~g}$ & 3,225 & 1,566 & 23,050 & 32,975 & 3,488 & 3,490 \\
\hline
\end{tabular}

Dari Tabel 5 dapat dilihat bahwa semakin banyak jumlah daging buah kurma yang ditambahkan maka pada uji kadar air, kadar abu, gula reduksi dan sakarosa semakin meningkat pada setiap masing-masing perlakuan sedangkan organoleptik rasa dan tekstur mengalami penurunan.

Tabel 6. Pengaruh Penambahan Ekstrak Lemon Dengan Parameter yang Diamati

\begin{tabular}{cccccccc}
\multicolumn{2}{c}{ Tabel 6. Pengaruh Penambahan Ekstrak Lemon Dengan Parameter yang Diamati } \\
\hline \multirow{2}{*}{$\begin{array}{c}\text { Ekstrak } \\
\text { Lemon } \\
(\mathbf{m l})\end{array}$} & $\begin{array}{c}\text { Kadar } \\
\text { Air }\end{array}$ & $\begin{array}{c}\text { Kadar } \\
\mathbf{( \% )}\end{array}$ & $\begin{array}{c}\text { Abu } \\
(\%)\end{array}$ & $\begin{array}{c}\text { Kadar } \\
\text { Gula } \\
\text { Reduksi } \\
(\%)\end{array}$ & $\begin{array}{c}\text { Sakarosa } \\
(\%)\end{array}$ & Rasa & Tekstur \\
\cline { 6 - 8 } & $\mathrm{L}_{1}: 30 \mathrm{~g}$ & 3,650 & 2,086 & 24,038 & 33,488 & 3,503 & 3,508 \\
$\mathrm{~L}_{2}: 25 \mathrm{~g}$ & 3,525 & 2,158 & 23,875 & 33,538 & 3,420 & 3,420 \\
$\mathrm{~L}_{3}: 20 \mathrm{~g}$ & 3,463 & 2,191 & 23,813 & 33,613 & 3,358 & 3,359 \\
$\mathrm{~L}_{4}: 15 \mathrm{~g}$ & 3,300 & 2,228 & 23,763 & 33,863 & 3,213 & 3,213 \\
\hline
\end{tabular}

Dari Tabel 6 dapat dilihat bahwa semakin banyak jumlah ekstrak lemon yang ditambahkan maka Uji Kadar air, Gula reduksi, rasa dan tekstur semakin meningkat pada setiap masing-masing perlakuan sedangkan uji kadar abu dan sakarosa mengalami penurunan.

\section{Kadar Air}

Pengaruh Jumlah Daging Buah Kurma

Pada perlakuan $K_{1}$ berbeda sangat nyata dengan perlakuan $K_{2}$, perlakuan $K_{3}$ dan 
perlakuan $\mathrm{K}_{4}$. Perlakuan $\mathrm{K}_{2}$ berbeda sangat nyata dengan perlakuan $\mathrm{K}_{3}$ dan perlakuan $\mathrm{K}_{4}$. Perlakuan $\mathrm{K}_{3}$ berbeda sangat nyata dengan perlakuan $\mathrm{K}_{4}$. Kadar air tertinggi terdapat pada perlakuan $\mathrm{K}_{1}$ sebesar $3,755 \%$ dan terendah $\mathrm{K}_{4}$ sebesar 3,225 \% untuk lebih jelasnya dapat dilihat pada Gambar 1.

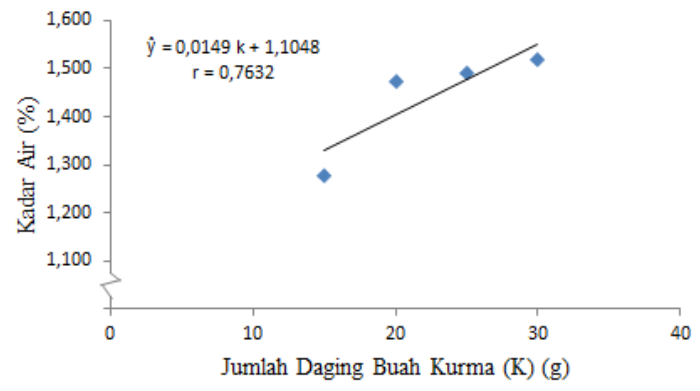

Gambar 1. Pengaruh kadar air terhadap Jumlah daging buah kurma

Hasil menunjukkan jika jumlah daging buah kurma yang ditambahkan semakin banyak, kadar air yang dihasilkan meningkat. Kandungan air dalam buah kurma cukup tinggi, yakni sebesar $21 \mathrm{~g}$ per $100 \mathrm{~g}$ buah kurma. Sebab yang mempengaruhi kualitas permen adalah kadar air, oleh karena itu kadar air sangat berhubungan dengan keawetan masa simpan dari permen yang dikandungnya, Wahyuni (1998).

\section{Pengaruh Penambahan Ekstrak Lemon}

Pada perlakuan $\mathrm{L}_{1}$ berbeda sangat nyata dengan perlakuan $L_{2}$, perlakuan $L_{3}$ dan perlakuan $\mathrm{L}_{4}$. Perlakuan $\mathrm{L}_{2}$ berbeda sangat nyata dengan pelakuan $\mathrm{L}_{3}$ dan perlakuan $\mathrm{L}_{4}$. Perlakuan $L_{3}$ berbeda sangat nyata dengan pelakuan $\mathrm{L}_{4}$. Kadar air tertinggi terdapat pada perlakuan $\mathrm{L}_{1}$ sebesar $3,650 \%$ dan terendah pada perlakuan $\mathrm{L}_{4}$ sebesar $3,300 \%$. Lebih jelasnya dapat dilihat pada Gambar 2.

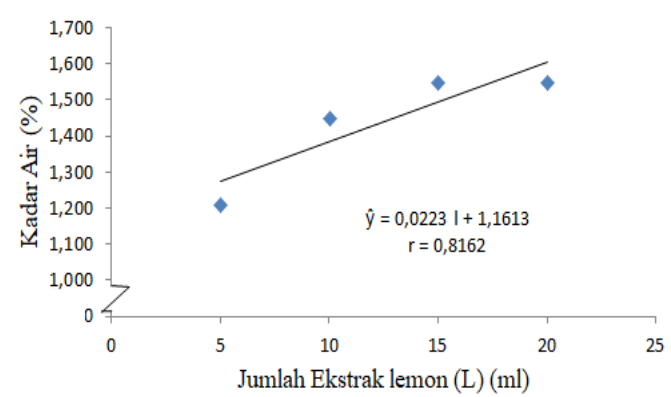

Gambar 2. Pengaruh kadar air terhadap Penambahan ekstrak lemon

Semakin banyak ekstak lemon yang ditambahkan maka kadar air pada permen soft candy akan mengalami peningkatan. Dikarenakan kandungan air pada buah lemon yang cukup tinggi yakni sebesar $86 \mathrm{ml}$ per 100 $\mathrm{g}$ buah lemon. Jika ekstrak lemon yang digunakan sedikit menyebabkan kadar air otomatis menurun. Pernyataan Juwita, et al., (2014), lemon merupakan buah yang mengandung asam sitrat yang tinggi. Dengan adanya kandungan asam sitrat yang tinggi tersebut, ekstrak lemon dapat digunakan sebagai pengental karena asam sitrat dapat mengikat bahan dengan baik .

\section{Hubungan Interaksi Antara Jumlah Daging Buah Kurma dan Penambahan Ekstrak Lemon pada Permen}

Hasil tertinggi yaitu pada jumlah daging buah kurma pada perlakuan $\mathrm{K}_{1}$ sebanyak $30 \mathrm{~g}$ dan penambahan ekstrak lemon $20 \mathrm{ml}$ pada perlakuan $\mathrm{L}_{1}$ sebesar $1,760 \%$ dan terendah yaitu pada jumlah daging buah kurma sebanyak 15 ml pada perlakuan $\mathrm{K}_{4}$ dan ekstrak lemon sebanyak $5 \mathrm{ml}$ pada perlakuan $\mathrm{L}_{1}$ yaitu $0,430 \%$. Hubungan interaksi jumlah daging buah kurma dan ekstrak lemon terhadap kadar air dapat dilihat pada Gambar 3.

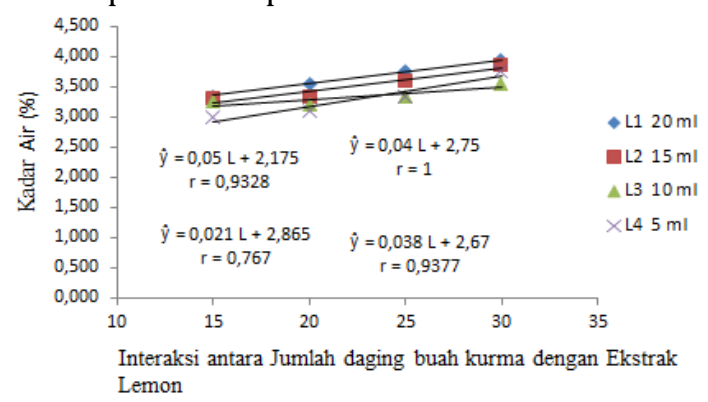

Gambar 3. Hubunga interaksi antara jumlah daging buah kurma dan penambahan ekstrak lemon pada permen

Semakin banyak jumlah daging buah kurma dan ekstrak lemon yang ditambahkan maka kadar air permen akan semakin meningkat, sebaliknya semakin sedikit penambahan ekstrak lemon maka akan semakin menurun kadar air nya. Hal ini di sebabkan kadar air yang terukur terdiri dari air bebas dan air terikat lemah. Menurut Sudarmadji, dkk., (2007), air bebas terdapat dalam ruang-ruang antar sel dan inter-granular dan pori-pori yang terdapat pada bahan. Air terikat secara lemah karena terserap (ter absorbsi) pada permukaan koloid makromolekuler seperti protein. Selain itu air juga terdispersi diantara koloid tersebut dan merupakan pelarut zat zat yang ada dalam permen. Air yang ada dalam bentuk ini masih tetap mempunyai sifat air bebas dan dapat dikristalkan pada proses pembekuan. Ikatan antara air dengan koloid tersebut merupakan ikatan hidrogen (Hull, 2010).

\section{Kadar Abu \\ Pengaruh Jumlah Daging Buah Kurma}


Pada perlakuan $\mathrm{K}_{1}$ berbeda sangat nyata dengan $\mathrm{K}_{2}, \mathrm{~K}_{3}$ dan $\mathrm{K}_{4}$. $\mathrm{K}_{2}$ berbeda sangat nyata dengan $\mathrm{K}_{3}$ dan $\mathrm{K}_{4}$. $\mathrm{K}_{3}$ tidak berbeda nyata dengan $\mathrm{K}_{4}$. Kadar abu yang tertinggi terdapat pada perlakuan $\mathrm{K}_{1}$ sebesar 2,721 \% dan terendah $\mathrm{K}_{4}$ sebesar 1,566\%. untuk lebih jelasnya dapat dilihat pada Gambar 4.

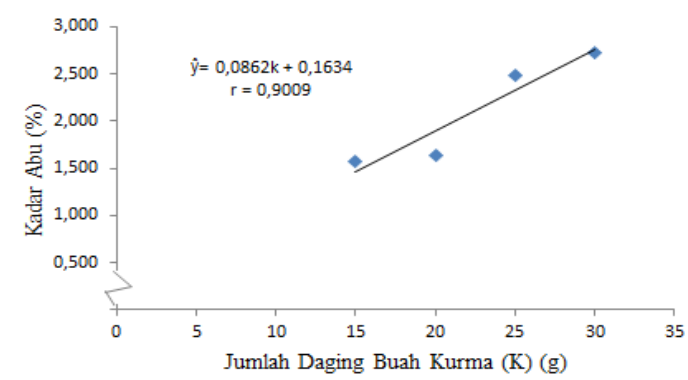

Gambar 4. Pengaruh Jumlah daging buah kurma terhadap kadar abunya

Semakin banyak ditambahkan daging buah kurma maka kadar abu akan yang dihasilkan tinggi. Disebabkan daging buah kurma yang mengandung banyak mineral. Pernyataan Gemilang, (2012), penentuan kualitas mutu dai permen dipengauhi oleh kadar abu, dimana kadar abu sendiri sangat berpengaruh dalam poses pengolahan permen. Bila kadar abu pada bahan baku pembuatan permen cukup baik, maka permen yang dihasilkan dapat memenuhi syarat mutu permen soft candy (Nurwati, 2011).

\section{Gula Reduksi \\ Pengaruh Jumlah Daging Buah Kurma}

Pada perlakuan $K_{1}$ berbeda sangat nyata dengan perlakuan $\mathrm{K}_{2}, \mathrm{~K}_{3}$ dan $\mathrm{K}_{4}$. Perlakuan $\mathrm{K}_{2}$ berbeda sangat nyata dengan perlakuan $\mathrm{K}_{3}$ dan $\mathrm{K}_{4}$. Perlakuan $\mathrm{K}_{3}$ berbeda sangat nyata dengan perlakuan $\mathrm{K}_{4}$. Gula reduksi tertinggi terdapat pada perlakuan $\mathrm{K}_{1}$ yakni $24,625 \%$ dan kadar gula reduksi terendah terdapat pada perlakuan $\mathrm{K}_{4}$ yakni 23 , 050\%. Untuk lebih jelasnya dapat dilihat pada gambar 5 .

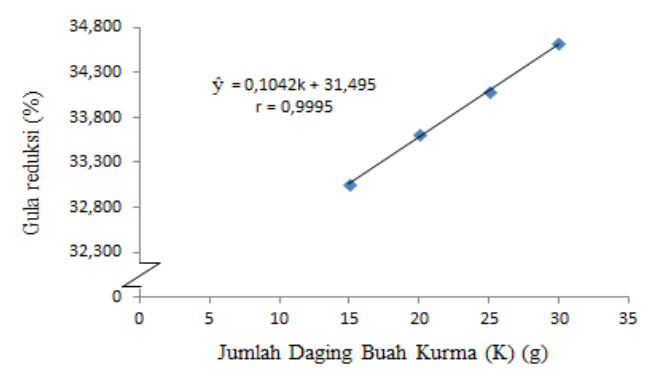

Gambar 5. Pengaruh Jumlah daging buah kurma terhadap persentase gula tereduksi

Pemanasan akan meningkatkan kadar gula reduksi dari permen kurma. Santoso dan Ranti (1999), mengatakan bahwa kandungan karbohidrat pada kurma cukup besar yaitu
6,23 g per $100 \mathrm{~g}$ kurma sehingga menyebabkan kenaikan kadar gula reduksi permen jika kadar konsentrasi dinaikkan.

Pemanasan dalam kondisi asam dengan perbandingan yang berbeda-beda menyebabkan terjadinya hidrolisis sehingga menghasilkan gula reduksi yang berbeda-beda. Ketika sukrosa dip

Panaskan maka selanjutnya mengalami pemecahan sukrosa menjadi fruktosa dan glukosa yang dipengaruhi oleh asam dan panas sehingga asam dan panas semakin meningkat. Sesuai dengan pernyataan Winarno (1997), yang menyatakan bahwa gula reduksi dapat mengalami peningkatan disebabkan pengaruh panas dan asam. Pengaruh panas dan asam meningkatkan kelarutan gula pada permen yang dapat menyebabkan sukrosa menjadi glukosa dan fruktosa pecah.

\section{Pengaruh Penambahan Ekstrak Lemon}

Pada perlakuan $\mathrm{K}_{1}$ berbeda nyata dengan $\mathrm{K}_{2}, \mathrm{~K}_{3}$ dan $\mathrm{K}_{4}$. $\mathrm{K}_{2}$ berbeda nyata dengan $\mathrm{K}_{3}$ dan $\mathrm{K}_{4} . \mathrm{K}_{3}$ berbeda nyata dengan $\mathrm{K}_{4}$. Gula reduksi yang tertinggi terdapat pada perlakuan $\mathrm{K}_{1}$ sebesar 24,038\% dan terendah $\mathrm{K}_{4}$ sebesar 23, $763 \%$. Untuk lebih jelasnya dapat dilihat pada Gambar 6.

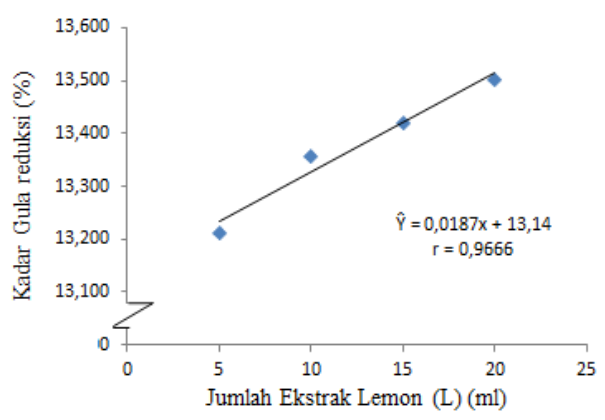

Gambar 6. Penambahan ekstrak lemon terhadap kadar gula reduksi

Semakin banyak kandungan asam yang tambahkan maka semakin meningkat kandungan gula reduksinya. Hal ini dikarenakan pada kadar gula pereduksi dari permen soft candy dengan penambahan ekstrak lemon cenderung meningkat karena sifat asam dari buah lemon yang ditambahkan. Permen yang diproses menggunakan penambahan buah yang bersifat asam akan memiliki gula reduksi yang tinggi karena sebagian sukrosa akan terinversi menjadi gula reduksi yaitu glukosa, fruktosa atau campuran keduanya (gula invert). Gula pereduksi terbentuk karena terjadinya proses inverse ataupun hidrolisis asam dari sukrosa menjadi glukosa dan fruktosa. Keterangan 
Winarno (2008), menyatakan gula reduksi dapat meningkat bila melewati proses pemasakan. Sukrosa mengalami pemecahan menjadi fruktosa dan glukosa disebabkan pengaruh panas dan asam sehingga gula mengalami peningkatan. Sesuai pendapat Ashurts, (1991) dengan adanya pemanasan, reaksi asam serta kandungan mineral yang terpisah maupun dikombinasikan, maka dapat menyebabkan proses inversi.

\section{Uji Sakarosa}

\section{Pengaruh Jumlah Ekstrak Lemon}

Pada perlakuan $\mathrm{K}_{1}$ berbeda sangat nyata dengan perlakuan $\mathrm{K}_{2}, \mathrm{~K}_{3}$ dan $\mathrm{K}_{4}$. Perlakuan $\mathrm{K}_{2}$ berbeda nyata dengan perlakuan $\mathrm{K}_{3}$. Perlakuan $\mathrm{K}_{3}$ berbeda nyata dengan perlakuan $\mathrm{K}_{4}$. Sakarosa yang tertinggi terdapat pada perlakuan $\mathrm{K}_{1}$ sebesar 34, 525\% dan terendah pada perlakuan $\mathrm{K}_{4}$ sebesar $32,975 \%$. untuk lebih jelasnya dapat dilihat pada Gambar 7.

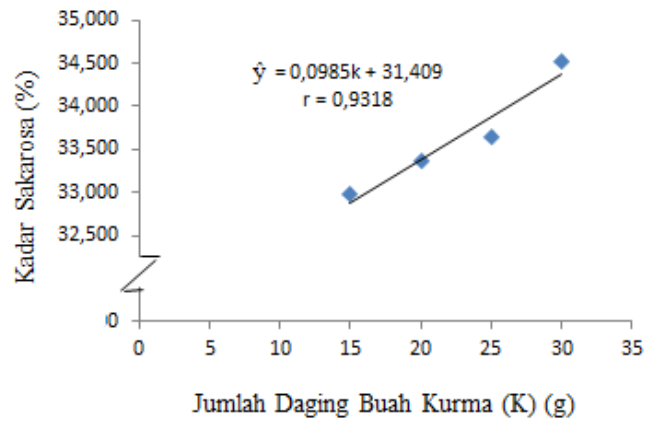

Gambar 7. Pengaruh Jumlah daging buah kurma terhadap kadar sakrosanya

Semakin banyak jumlah daging buah kurma banyak digunakan maka sakarosa akan meningkat. Pemasakan sukrosa menyebabkan pemecahan sukrosa menjadi fruktosa serta glukosa. Keterangan Winarno (1997), gula pereduksi mengalami peningkatan selama dilakukan poses pemasakan sehingga mengalami pemecahan menjadi fruktosa serta glukosa akibat pengaruh panas dan asam sehingga kelarutan gula akan meningkat.

\section{Organoleptik Rasa \\ Pengaruh Jumlah Daging Buah Kurma}

Pada perlakuan $\mathrm{L}_{1}$ berbeda nyata dengan perlakuan $\mathrm{L}_{2}, \mathrm{~L}_{3}$ dan $\mathrm{L}_{4}$. Perlakuan $\mathrm{L}_{2}$ berbeda nyata dengan perlakuan $\mathrm{L}_{3}$ dan $\mathrm{L}_{4}$. Perlakuan $\mathrm{L}_{3}$ berbeda nyata dengan perlakuan $\mathrm{L}_{4}$. Organoleptik rasa tertinggi terdapat pada perlakuan $\mathrm{L}_{1}$ sebesar 3,503 \% dan terendah pada perlakuan $\mathrm{L}_{4}$ sebesar 3, $213 \%$. Lebih jelasnya dapat dilihat pada gambar 8 .

Citarasa sedikit asam karena penambahan lemon. Penambahan sukrosa dan sirup fruktosa sama setiap perlakuan dan yang membedakan hanya pada penambahan bahan baku seperti kurma dan ekstrak lemon.

Lemon mengandung rasa lebih asam dari pada kurma, sehingga rasa permen yang dihasilkan agak asam. Penilaian sensori terhadap rasa permen yang dihasilkan dipengaruhi oleh rasa asam-asam manis yang dihasilkan dari perpadun kurma dengan lemon.

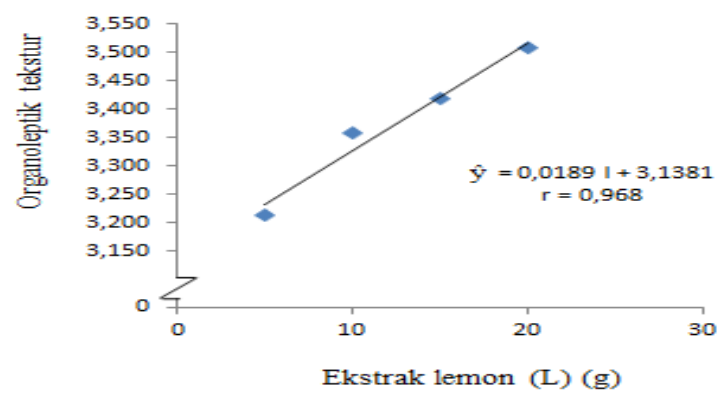

Gambar 8. Uji organoleptik rasa terhadap penambahan ekstrak lemon

Kondisi asam ini dipengaruhi oleh adanya kandungan asam sitrat pada pembuatan soft candy. Menurut Buckle, dkk., (2007), kondisi asam penting terhadap pembentukan struktur pada permen soft candy. Keterangan Fardiaz, (1992), asam makanan dapat diperoleh karena kandungan pada bahan makanan itu sendiri.

\section{Organoleptik Tekstur}

\section{Pengaruh Penambahan Ekstrak Lemon}

Pada perlakuan $\mathrm{L}_{1}$ berbeda nyata dengan $L_{2}$, $L_{3}$ dan $L_{4}$. Perlakuan $L_{2}$ berbeda nyata dengan perlakuan $\mathrm{L}_{3}$ dan $\mathrm{L}_{4}$. Perlakuan $\mathrm{L}_{3}$ berbeda nyata dengan perlakuan $\mathrm{L}_{4}$. Organoleptik tekstur tertinggi terdapat pada perlakuan $\mathrm{L}_{1}$ sebesar 3,508 \% dan terendah pada perlakuan $\mathrm{L}_{4}$ sebesar 3, $213 \%$. Lebih jelasnya dapat dilihat pada gambar 9.

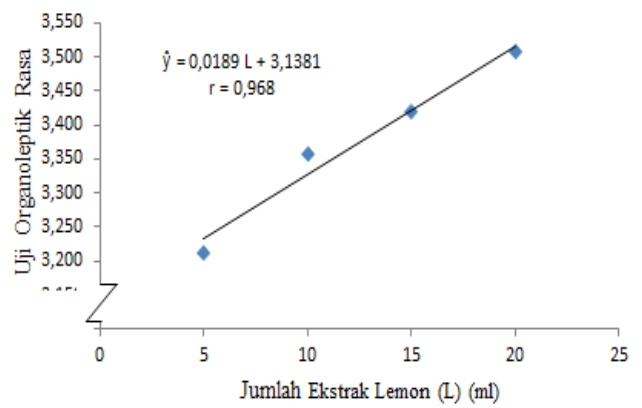

Gambar 9. Uji organoleptic rasa terhadap penambahan ekstrak lemon

Semakin tinggi ekstrak lemon yang ditambahkan maka semakin lunak tekstur yang dihasilkan karena kandungan asam sitrat yang terkandung pada lemon. Asam sitrat ini dapat berfungsi sebagai pengikat pada bahan agar permen yang dihasilkan menjadi lunak. Selain 
Junniatunnisa BR Sitepu and Zulkifli Lubis / Agrintech | Jurnal Teknologi Pangan dan Hasil Pertanian 2 (2) 2019, 61-67

kandungan asam sitrat, kandungan pektin yang terdapat pada lemon juga dapat mempengaruhi tingkat kelunakan dari permen yang dihasilkan (Wijana, dkk., 2014) mengemukakan bahwa asam diperlukan untuk membantu mengokohkan jaringan gel. Tekstur merupakan komponen yang turut menentukan citarasa makanan karena sensitivitas indera dipengaruhi oleh konsistensi makanan (Saskia, 2016).

\section{KESIMPULAN DAN SARAN Kesimpulan}

Dari Hasil Penelitian dapat

disimpulkan bahwa:

1. Pada konsetrasi kurma memberikan pengaruh berbeda sangat nyata $(p<0,01)$ pada parameter Kadar air, Kadar Abu, Gula reduksi, Sakarosa. Sedangkan parameter Organoleptik Rasa, Organoleptik Tekstur memberikan pengaruh tidak nyata ( $p>0,05)$.

2. Pada konsentrasi lemon memberikan pengaruh berbeda sangat nyata $(p<0,01)$ pada parameter Kadar air, Gula Reduksi, Organoleptik Rasa, Organoleptik Tekstur. Sedangkan parameter Kadar Kadar Abu, Sakarosa memberikan pengaruh tidak nyata ( $>00,05)$.

3. Interaksi pada konsentrasi kurma dan lemon memberikan pengaruh yang berbeda sangat nyata $(\mathrm{p}<0,01)$ pada analisis Kadar air.

\section{Saran}

Disarankan kepada peneliti selanjutnya agar mengembangkan penelitian ini menggunakan metode pemanasan dengan suhu yang lebih rendah agar mengurangi perubahan rasa pada permen yang dihasilkan pada. Serta menambahkan parameter pengujiannya seperti kadar serat, total asam, vitamin C

\section{DAFTAR PUSTAKA}

Cahyo. A. 2010. Sejuta Khasiat Susu Unta \& Sari Kurma. Semarang : Sabil.

Bone, K. 2013. Principles and Practice of Phytotherapy Modern Herbal Medicine. Elseveir, USA.

Nizhar, U.M. 2012. Level Optimum Sari Buah Lemon (Citrus limon) sebagai Bahan Penggumpal pada Pembentukan Curd Keju Cottage. Makasar : Skripsi Program Studi Teknologi Hasil Ternak. Jurusan
Produksi Ternak. Fakultas Peternakan. Universitas Hasanudin.

Wahyuni, H.D. (1998). Mempelajari Pembuatan Hard Candy dari Gula Invert Sebagai Alternatif Pengganti Sirup Glukosa. Skripsi. Bogor: Institut Pertanian Bogor.

Juwita, W., H. Rusmarilin., dan E. Yusraini. 2014. Pengaruh Konsentrasi Pektin dan Karagenan Terhadap Mutu Permen Jely Jahe. Jurnal Rekayasa Pangan dan Pertanian. Volume 2. Nomor 2: Hal : 4250. Ilmu dan Teknologi Pangan

Sudarmadji, S., Suhardi, dan B. Haryono. 1984. Analisa Bahan Makanan dan Bahan Pertanian. Penerbit Liberty, Yogyakarta Hal: 25-70.

Hull, P. 2010. Glucose Syrup: Technology and Applications. New York : John Wiley and Sons, Inc.

Gemilang, J. 2012. 1001 Aneka Buah dan Sejuta Khasiatnya Ampuh Mengatasi Beragam Penyakit. Yogyakarta: Araska.

Nurwati, 2011. Formulasi Hard Candy dengan Penambahan Ekstrak Buah Pedada (Sonneratia caseolaris) Sebagai Flavor. Skripsi Fakultas Perikanan dan Ilmu Kelautan Institut Pertanian Bogor

Santoso,S.dan A.L.Ranti,1999. Kesehatan dan Gizi. Jakarta : Rineka Cipta.

Winarno, F.G. 1997. Kimia Pangan dan Gizi. Gramedia Pustaka Umum. Jakarta

Winarno, F. G. 2008. Kimia pangan dan gizi. PT. Gramedia Pustaka Utama. Jakarta.

Ashurst, P.R. 1991. Food Flavorings. UK: Chapman \& Hill.

Buckle, K. A., R. A. Edwards., G. H. Fleet dan M. Wotton. 2007. Ilmu Pangan. Terjemahan.

Wijana, S., A. F. Mulyadi., dan T. D. T. Septivirta. 2014. Pembuatan Permen Jelly dari Buah Nanas (Ananas Comosus L.) Subgrade (Kajian Konsentrasi Karagenan dan Gelatin). Jurnal Teknologi Pertanian. http://skripsitipftp.staff.ub.ac.id/files/2 
014/10/JURNAL-Theresia-Dyan-Tiara-

Septivirta.pdf._Diakses pada 28 Mei

2019.

Saskia, R. 2016. Pemanfaatan rebung betung (Dendrocalamus asper) dalam pembuatan pikel. Skripsi. Fakultas Pertanian. Universitas Riau. Pekanbaru.

Fardiaz, S. 1992. Mikrobiologi Pengolahan Pangan. Departemen Pendidikan dan Kebudayaan. Direktrat Jendral Pendidikan Tinggi. Pusat Antar Universitas Pangan dan Gizi. Institut Pertanian Bogor. Bogor 